\section{ART OF NOISE}

An early collaboration between engineers at Bell Laboratories in New Jersey and ten artists, among them Robert Rauschenberg, Robert Whitman and John Cage, is highlighted in an exhibition at New York's Museum of Modern Art.

The group built and featured novel technical equipment in avant-garde theatre and dance performances in October 1966 in New York. This formed part of a wider programme by Experiments in Art and Technology, an organization that promoted crossover projects until the 1980 s.

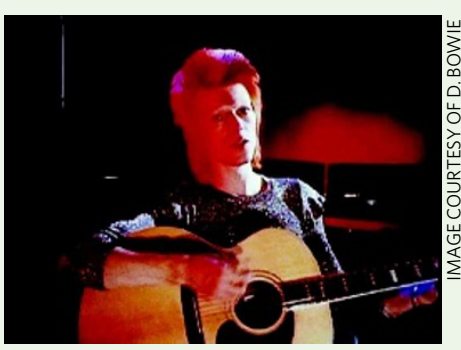

Looking at Music, which runs until January 2009, explores how music, art and technology have influenced each other since the innovations of video and electric guitars in the 1960s. On display are video, audio and photographic works by artists such as Laurie Anderson, Nam June Paik and Bruce Nauman. Films accompany the show and track developments in technologies, including those in early music videos by The Beatles, David Bowie (pictured) and Captain Beefheart http://tinyurl.com/5gakt6

\section{SMILES OF SUCCESS}

Portraits of Nobel prizewinners by the German photographer Peter Badge are collected in Nobels, published by

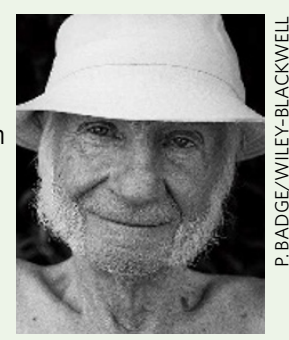

Wiley this

month. Badge has tracked down and photographed more than 300 living Nobel laureates for this glossy coffeetable book, including economist John Nash and physicist Hans Dehmelt (pictured). A biography is presented alongside each portrait.

http://tinyurl.com/5qmu7s the breathless pace of his prose leads him to make glib generalizations, a check of a few sources creates serious doubts about the way in which he summarizes their research findings. Perhaps he has not had time to assimilate them adequately. Levitin's text gives the impression of an assignment by a highly intelligent student who has done so much preliminary reading and assembled so many references that he cannot discipline himself to omit a single one. Not all research is good or worthwhile and, in such a book, more is not necessarily better. Stricter selectivity would have helped.

The writing is a problem, too. Much of it reads as if it was dictated into a machine and given the most cursory of edits. Many sentences are needlessly opaque. Some paragraphs are trivial and others are contradictory; his accounts of outcomes of experiments differ - a serious flaw - and incompatible 'facts' are given, such as about the sensitivity of auditory hair cells. In places the writing seems lazy, as with his over-use of the phrase "neurochemical soup". One questions his understanding of some material, such as an assertion that "grammar specifies rules ... based on where in the sentence the elements appear", which betrays an unawareness of Latin and German. Worst of all are the pages of self-indulgent digression from his grand, and essentially unprovable, thesis that "the musical brain created human nature". The book should have been much shorter and better constructed.

Why has Levitin written it? I suspect that it was at the publisher's urging, after the success of his far superior earlier book. The reader's time would be better spent with that previous book or by engaging with the research articles that Levitin draws on. One would then also be spared the boastful confusion of friends and anecdotes, the sheer volume of which the scientific brain, let alone the musical brain, struggles to deal with.

John Carmody is a medical scientist at the University of Sydney, Australia, who writes and broadcasts on music and scientific history. e-mail:jcarmody@med.usyd.edu.au

\title{
Innovations of an ancient nation
}

Chinese Memory: Treasures of a

5,000-year-old Civilization

Capital Museum, Beijing

Until 7 October 2008

This ancient Chinese 'environmentally friendly' oil lamp (pictured) has a built-in system to eliminate smoke and dates from the Western Han dynasty of $206 \mathrm{BC}$ to $\mathrm{AD} 25$. It is one of 169 artefacts on display in the exhibition Chinese Memory, showing at the Capital Museum in Beijing until October. The items, ranging from a 6,000 BC flute to a twentieth-century incense burner, were chosen from 55 museums across the country to trace China's technological and cultural innovations.

The bronze oil lamp was excavated in Pingsu, Shanxi province, in 1985. It takes the shape of a swan goose turning its neck backwards, holding a fish in its mouth. A round burner sits on the bird's back, shaded by the fish. Two curved bronze panels make an adjustable shutter for the burner, and can be slid open or closed to shelter the flame from wind and to control the illumination level. When the lamp is lit, smoke rises into the bird's mouth and is channelled via the neck into the belly, where it is trapped by water. Assembled from four components, it can be taken apart for cleaning.

The lamp's form reflects a fusion of philosophies. During the early Han period, the emperors co-opted many ideologies that had been suppressed by the preceding Qin dynasty (221-206 BC), during which scholarly books were burned and Confucians buried alive. The lamp combines Confucianism's regard for utility with Taoism's respect for living in accord

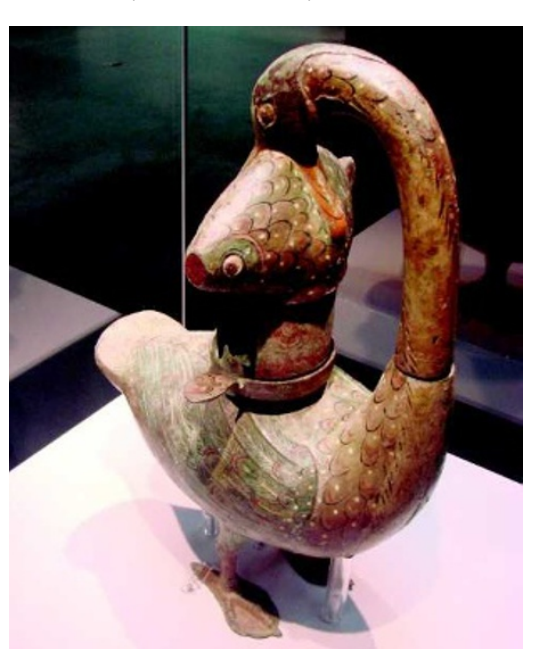
with nature. The swan goose symbolizes compassion and blessing and the fish represents prosperity.

By embodying the traditional Chinese ideal of tianren heyi - the harmony between man and nature - this exquisite lamp's design points to the early desire among the ancients to live in a clean environment. Jane Qiu is a science writer based in London and Beijing. e-mail:jane@janeqiu.com 